\title{
Agricultural management systems affect on physical, chemical and microbial soil properties
}

Elaine Reis Pinheiro Lourente ${ }^{1}$, Eulene Francisco da Silva ${ }^{2}$, Fábio Martins Mercante ${ }^{3}$, Ademar Pereira Serra**4 $^{*}$, Paula Pinheiro Padovese Peixoto ${ }^{5}$, Rodrigo Cesar Sereia ${ }^{4}$, Simone Cândido Ensinas ${ }^{5}$, Antonio Luiz Neto Neto ${ }^{6}$, Alessandra Mayumi Tokura Alovisi ${ }^{7}$, Marlene Estevão Marchetti ${ }^{7}$, Jorge Wilson Cortez $^{7}$

${ }^{1}$ Universidade Federal da Grande Dourados (UFGD), Post Graduation Program in Agricultural Engineer, City of Dourados, State of Mato Grosso do Sul, Brazil

${ }^{2}$ Faculdade de Ciências Agrárias/Universidade Federal Rural do Semi-Árido (UFERSA), City of Mossoró, State of Rio Grande do Norte, Brazil

${ }^{3}$ Brazilian Agricultural Research Corporation (EMBRAPA Western Agriculture), City of Campo Grande, State of Mato Grosso do Sul, Brazil

${ }^{4}$ Brazilian Agricultural Research Corporation (EMBRAPA Beef Cattle), City of Campo Grande, State of Mato Grosso do Sul, Brazil

${ }^{5}$ Universidade Estadual de Mato Grosso do Sul, City of Cassilândia, State of Mato Grosso do Sul, Brazil

${ }^{6}$ Agronomist, independent consultant

${ }^{7}$ Universidade Federal da Grande Dourados (UFGD), Post-Graduation Program in Agronomy-Crop Science Department, City of Dourados, State of Mato Grosso do Sul, Brazil

*Corresponding author: ademar.serra@embrapa.br

\begin{abstract}
The purpose of this research was to assess the effects of replacement of native "Cerrado" vegetation (NV) into croplands on soil chemical, physical and microbial properties. This research was carried out on a farm under Rhodic Hapludox soil with different types of agricultural managements systems, and it was used a NV to compare the systems. The experimental design was set up in completely randomized with five treatments and five repetitions. The treatments adopted were several agricultural management systems as follow; NV; CS_Crop system; LS_Livestock system; ICLS-4_Integrated crop-livestock system with four years of implementation; ICLS-8_Integrated crop-livestock system with eight years of implementation. It was assessed some chemical, physical, and microbial parameters in the soil, as soil $\mathrm{pH}, \mathrm{P}$ content, exchangeable cations, cation exchange capacity, base saturation, cations saturation, soil organic carbon (SOC), soil bulk density (SBD), aggregate stability, microbial biomass carbon (MBC), basal breathing, and microbial quotient. The replacement of NV to ICLS decreased SOC, MBC, soil aggregate stability and increase of SBD. The ICLS improved "Cerrado" soil fertility over time adoption. This integrated system increased the quantity of exchangeable $\mathrm{K}^{+}$and P content in "Cerrado" soil. The ICLS-8 showed soil environment nearby the NV. Even the difficulty in obtaining the same physical and microbial condition of NV, the results of this research point out quite important observations, because just no-till system is not enough to obtain improvement of soil quality and the ICLS can return the soil properties close to native "Cerrado" vegetation.
\end{abstract}

Keywords: Soil organic carbon, sustainability, conservation tillage, soil microbiology, integrated crop-livestock system. Abbreviations: Soil Organic Carbon_SOC; Soil Bulk Density_SBD; Integrated Crop-Livestock System_ICLS.

Introduction

The Brazilian "Cerrado" is the major spot to expansion of agricultural in Brazil, the "Cerrado" region is considered the last frontier of agriculture in the world. However, the replacement of "Cerrado" for cropland is leading to a problem in the environment, like soil erosion, biodiversity decrease, increase in soil bulk density, decrease in soil organic carbon etc. The Brazilian "Cerrado" region is coverage in the most part with forage grass, which is shown in process of degradation (Thomas, 1995). The replacement of forest into cropping systems ought to be very dangerous in term of soil physical, chemical and microbial properties. The biomass produced in a forest is in balance, with the replacement of forest into cropland leads to unbalance. It has been observed that the soil organic matter (SOM) in these croplands is decreasing over time (Braz et al., 2013), and it is a problem for sustainability of agricultural system of production (Valboa et al., 2015). It is important to implement conservational agricultural management systems that return to similar conditions of native vegetation, majority in terms of soil physical, organic carbon and microbial properties, which is a challenge to be overcoming. In this context, the no-till system associate with integrated crop-livestock system coming to be an alternative to recover soil quality in croplands (Batlle and Bayer et al., 2010). The decrease of soil organic carbon (SOC) is more intensity expected in tillage system (Sá et al., 2009), because of the movement of soil and 
organic matter closely associated with more oxygenation into the soil, these factors combined might increase the mineralization of SOM. These processes affect the soil aggregate stability, because of the breaking of soil aggregate and reducing the SOM (Peigné et al., 2007). Even in condition of agricultural system with high amount of aboveground dry matter, with the tillage of soil the dry matter decreases faster ending the benefits of crops residues in the soil (Laudicina et al., 2011).

Furthermore, it is important to keep in mind that crop rotation in this agricultural systems and cover crops during fall-winter season is the first step to keep these systems sustainable. An alternative to maintain the SOM in no-till system is the cultivation of cover crops with high potential of aboveground dry matter production associated with high dry matter half-life, these factors combined may remain the crops residues longer in soil (Balota et al., 2011). The forage grass (Brachiaria spp) in integrated crop-livestock system is very promise to increase SOC, because of high $\mathrm{C} / \mathrm{N}$ ratio and biomass production (Wendling, et al., 2012).

As reported by Silva et al. (2010), due to the absence of soil tillage in conservationist agricultural system, especially in no-till, it is possible to obtain increase of microbial biomass carbon and its compounds throughout the time of implementation that may affect positively the crop production.

The study of soil microbial is very relevant because of soil organic matter mineralization and phosphorus content availability (Gracía-Orenes et al., 2010), this type of study is limited in Brazilian "Cerrado". The changes in soil tillage may affect quickly the indicators of soil microbial (Silva et al., 2010). The purpose of this research was to assess the effects of replacement of native "Cerrado" vegetation into croplands with different types of agricultural management systems affects on soil chemical, physical and microbial properties.

\section{Results and Discussion}

Analysis of variance (ANOVA) of the parameters assessed

It was observed significant difference $(p \leq 0.01)$ for the most part of variables analyzed, the agricultural management system showed affects in soil chemical, physical and microbial properties (Table 1). In terms of soil $\mathrm{pH}_{\mathrm{CaCl} 2}$, exchangeable $\mathrm{Ca}^{+2}, \mathrm{Ca}^{+2}$ and $\mathrm{Mg}^{+2}$ saturation, base saturation and quotient microbial $(q \mathrm{MIC})$, no significant difference (p>0.05) was observed for these variables (Table 1). It means that in comparison to native "Cerrado" vegetation, these chemical and microbial properties showed equal value in terms of statistical analysis. It was expected higher soil $\mathrm{pH}$ in agricultural management systems due to the liming application to correct the soil acidity. But, the liming management in no-till system is taken and incorporated just in the beginning of the agricultural system implementation, over time, the liming procedure is broadcast on the soil surface, which decrease the chance in correcting the soil $\mathrm{pH}$ in deeper layers. It is possible that this procedure may influence in these results.

\section{Soil chemical properties affects by replacement of native “Cerrado" vegetation to croplands}

The replacement of native "Cerrado" vegetation (NV) area into an integrated crop-livestock system (ICLS) decreases the cation exchange capacity (CEC) in cropping system (CS), livestock system (LS), integrated crop-livestock system with four years of implementation (ICLS-4). On the other hand, the CEC did not differ ( $>0.05)$ between NV and integrated crop-livestock with eight years of implementation (ICLS-8), these results is quite important to observe the capacity of ICLS in increasing CEC through time of implementation (Fig 1A). The NV is a reference for CEC, because of high amount in SOC and consequently CEC, this way the absence of difference and the proximity of CEC among both environment assure the importance of conservationist system to improve the soil quality. The replacement of $\mathrm{NV}$ into agricultural management systems increased exchangeable $\mathrm{K}^{+}$ in $369 \%$ and $\mathrm{P}$ content in $1,246 \%$ in relation to the ICLS-8 (Fig 1B and C). The Brazilian "Cerrado" soil has shown to be very poor in chemical properties and high exchangeable $\mathrm{Al}^{+3}$ with low available quantity of exchangeable $\mathrm{K}^{+}$and $\mathrm{P}$ content, however, the replacement of native "Cerrado" vegetation by agricultural system increase exchangeable $\mathrm{K}^{+}$ (ICLS-8) and P content over time of implementation (Fig 1B and $\mathrm{C}$ ). On the other hand, the $\mathrm{Al}^{+3}$ saturation and SOC decrease in all agricultural systems (Fig 1D and E).

The decrease of $\mathrm{Al}^{+3}$ saturation in topsoil $(10 \mathrm{~cm}$ depth) ought to be associated with liming broadcast to correct the soil acidity in agricultural system evaluated and high amount of SOC in top soil, that can complex the soluble $\mathrm{Al}^{+3}$. Even if no statistical difference $(\mathrm{p}>0.05)$ was observed by soil $\mathrm{pH}$, the Pearson's correlation between $\mathrm{Al}^{+3}$ saturation and soil $\mathrm{pH}$ was strong and negative $(r=-0.7102)$, which indicated the decrease of soil acidity effect on $\mathrm{Al}^{+3}$ saturation. Even with high $\mathrm{Al}^{+3}$ saturation in $\mathrm{NV}$, it is quite important to keep in mind that in soil of NV the content of SOC is much higher than in agricultural system in the most case, this fact may decrease the toxic effect of $\mathrm{Al}^{+3}$ in NV due to the $\mathrm{Al}^{+3}$ bound to organic complexes (Matús et al., 2006). The liming to correct the soil acidity as well as the fertilization with sources of $\mathrm{K}^{+}$and $\mathrm{P}$ contribute to increase soil fertility in this crop system evaluated in this research. Nevertheless, the ICLS-8 was the most responsible probably because of the longest time of duration. The P content in ICLS- 8 was $253 \%$ higher than ICLS-4, these results may reassure that the time of conservationist system implantation is important to obtain improvement in chemical soil (Fig 1C).

Beside the influence of $\mathrm{P}$ and $\mathrm{K}^{+}$fertilizer sources applied in the experimental area, the increment in $\mathrm{P}$ and $\mathrm{K}^{+}$through the time in ICLS- 8 can be due to the no-till and the release of $P$ by crops residues mineralization and input of cattle excreta. As reported by Garcia et al. (2011), the increase of P available in soil is due to increase the solubilizing activity in system with rotational grazing due to the highest input of organic matter from cattle excreta, which is used as source of carbon and energy for soil microbial activities. This increment in $\mathrm{P}$ availability is quite important because in Brazilian "Cerrado" most of soils are classified as Oxisol, which shows constraints in $\mathrm{P}$ due to its high capacity of $\mathrm{P}$ adsorption. As reported by Barroso and Nahas (2005), the soluble phosphate in the most soil in Brazil is quite low. To obtain enough supply of $\mathrm{P}$ for crops growth in these soils, it is necessary to fertilize with high quantity of $\mathrm{P}$ sources; because just $10-30 \%$ of the P applied can be recovered by crop growth (Syers et al., 2008).

The ICLS-8 showed $154.7 \%$ higher P content than the CS. These results are due to the high quantity of above-ground dry matter production from Brachiaria spp in the ICLS-8 associated with higher $\mathrm{P}$ uptake efficiency and deep roots. The Brachiaria spp shows a great efficiency in $\mathrm{P}$ uptake, even in low $\mathrm{P}$ content in soil, it is possible to observe that 
Table 1. Summary of analysis of variance (ANOVA).

\begin{tabular}{|c|c|c|c|c|c|}
\hline & Treatments & CV\% & & Treatments & $\mathrm{CV} \%$ \\
\hline Dependent variables & $F$-value & & Dependent variables & $F$-value & \\
\hline $\mathrm{pH} \mathrm{CaCl}{ }_{2}$ & $2.13^{\mathrm{ns}}$ & 6.34 & $\mathrm{~K}(\%)$ & $12.71 * *$ & 40.47 \\
\hline $\mathrm{Al}\left(\mathrm{mmolcdm}^{-3}\right)$ & $4.94 * *$ & 47.79 & $\mathrm{BS}(\%)$ & $2.63^{\mathrm{ns}}$ & 15.89 \\
\hline $\mathrm{Ca}\left(\right.$ mmolc dm $\left.{ }^{-3}\right)$ & $0.86^{\mathrm{ns}}$ & 20.35 & $\mathrm{Al}(\%)$ & $6.11 * *$ & 53.14 \\
\hline $\mathrm{Mg}\left(\mathrm{mmolc} \mathrm{dm}^{-3}\right)$ & $5.55^{* *}$ & 21.88 & $\mathrm{OC}$ & $80.41 * *$ & 7.52 \\
\hline $\mathrm{K}\left(\mathrm{mmolc} \mathrm{dm}^{-3}\right)$ & $10.14 * *$ & 47.71 & $\operatorname{SBD}\left(\mathrm{g} \mathrm{dm}^{-3}\right)$ & $12.36 * *$ & 7.81 \\
\hline$P\left(\mathrm{mg} \mathrm{dm}^{-3}\right)$ & $12.74 * *$ & 52.22 & $\operatorname{MWD}(\mathrm{mm})$ & $4.38 *$ & 3.27 \\
\hline $\mathrm{SB}$ mmolc $\mathrm{dm}^{-3}$ & $5.22 * *$ & 17.13 & MBC ( $\mu \mathrm{g}$ C/g of soil) & $17.33 * *$ & 14.05 \\
\hline CEC $\left(\right.$ mmolc $\left.\mathrm{dm}^{-3}\right)$ & $30.24 * *$ & 5.48 & $\mathrm{MB}\left(\mathrm{C}-\mathrm{CO}_{2}\right)$ & $91.04 * *$ & 7.50 \\
\hline $\mathrm{Ca}(\%)$ & $1.13^{\mathrm{ns}}$ & 19.76 & $q \mathrm{CO}_{2}\left(\mu \mathrm{g} \mathrm{CO}_{2} / \mu \mathrm{gC}_{\mathrm{mic}} \mathrm{h}^{-1}\right)$ & $10.11 * *$ & 14.61 \\
\hline $\operatorname{Mg}(\%)$ & $1.38^{\mathrm{ns}}$ & 22.58 & $q \operatorname{MIC}(\%)$ & $1.92^{\mathrm{ns}}$ & 52.39 \\
\hline
\end{tabular}
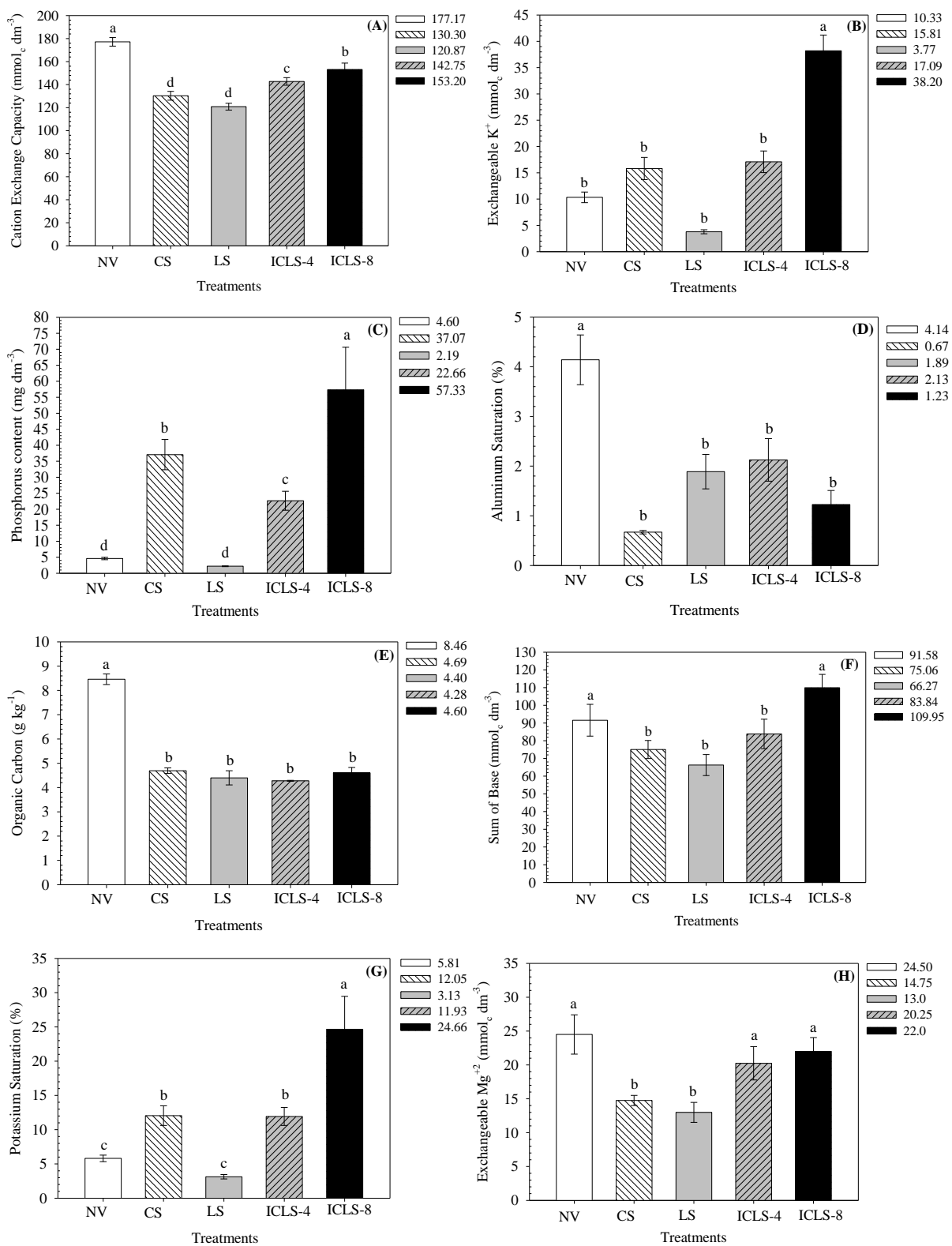

Fig 1. Soil chemical properties changes by replacement of native "Cerrado" vegetation to agricultural systems. NV_Native "Cerrado" vegetation; CS_Crop system; LS_Livestock system; ICLS-4_integrated crop-livestock system with 4 years of implementation; ICLS8_integrated crop-livestock system with 8 years of implementation. Mean in each bar followed by the same letter are not significantly different at $\mathrm{p} \leq 0.05$ according to Scott Knott's test of mean. 
Table 2. Mean \pm standard deviation of mineral granulometric analysis of the experimental site.

\begin{tabular}{lccc}
\hline \multirow{2}{*}{ Treatments } & Sand & Silt & Clay \\
\cline { 2 - 4 } & $234.4 \pm 0.53$ & $81.9 \pm 2.78$ & $683.7 \pm 2.83$ \\
NV & $185.7 \pm 0.37$ & $96.5 \pm 1.53$ & $717.7 \pm 1.89$ \\
LS & $169.3 \pm 0.39$ & $101.9 \pm 3.09$ & $728.7 \pm 2.74$ \\
ICLS-4 & $206.0 \pm 0.28$ & $77.9 \pm 0.73$ & $716.1 \pm 0.65$ \\
ICLS-8 & $226.6 \pm 0.49$ & $64.2 \pm 0.72$ & $709.2 \pm 0.34$ \\
\hline NV Native "Cerrado" vegetation; CS Crop system; LS_Livestock system; ICLS-4 Integrated crop-livestock system with 4 years of implementation; ICLS-8 Integrated
\end{tabular}

crop-livestock system with 8 years of implemstem;
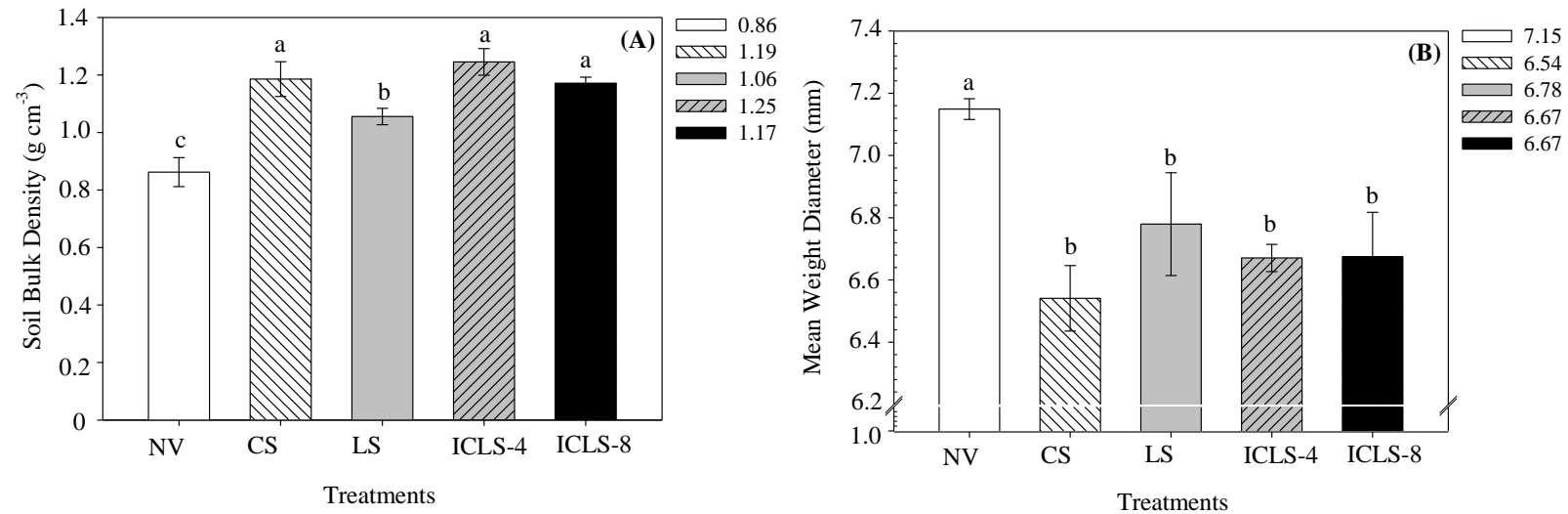

Fig 2. Agricultural management systems effects on soil bulk density and mean weight diameter. NV_Native "Cerrado" vegetation; CS_Crop system; LS_Livestock system; ICLS-4_integrated crop-livestock system with 4 years of implementation; ICLS8_integrated crop-livestock system with 8 years of implementation. Mean in each bar followed by the same letter are not significantly different at $\mathrm{p} \leq 0.05$ according to Scott Knott's test of mean.
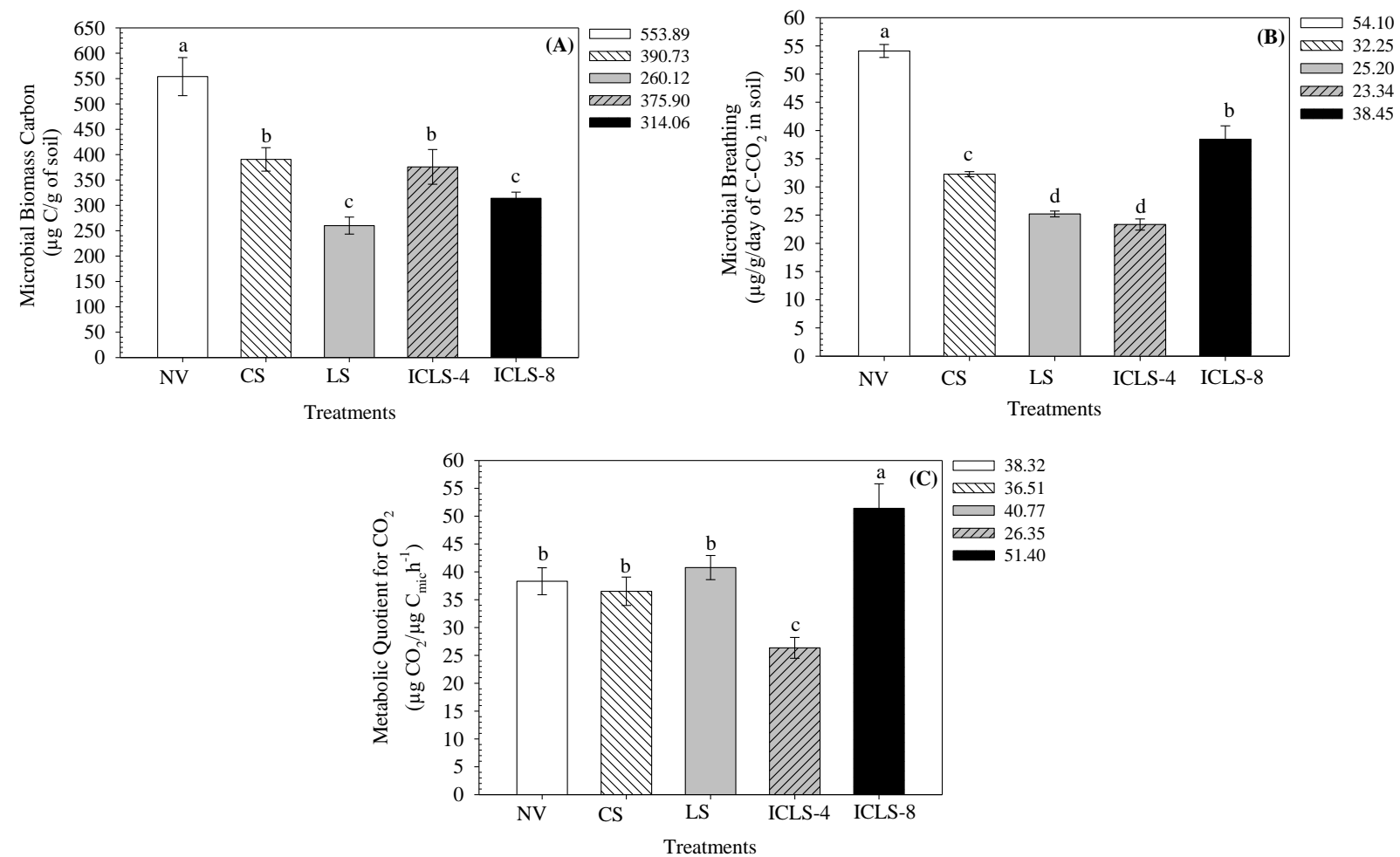

Fig 3. Agricultural management systems affects on metabolic quotient for $\mathrm{CO}_{2}\left(q \mathrm{CO}_{2}\right)$, microbial breathing (MB) and microbial biomass carbon (MBC). NV_Native "Cerrado" vegetation; CS_Crop system; LS_Livestock system; ICLS-4_integrated croplivestock system with 4 years of implementation; ICLS-8_integrated crop-livestock system with 8 years of implementation. Mean in each bar followed by the same letter are not significantly different at $\mathrm{p} \leq 0.05$ according to Scott Knott's test of mean. 


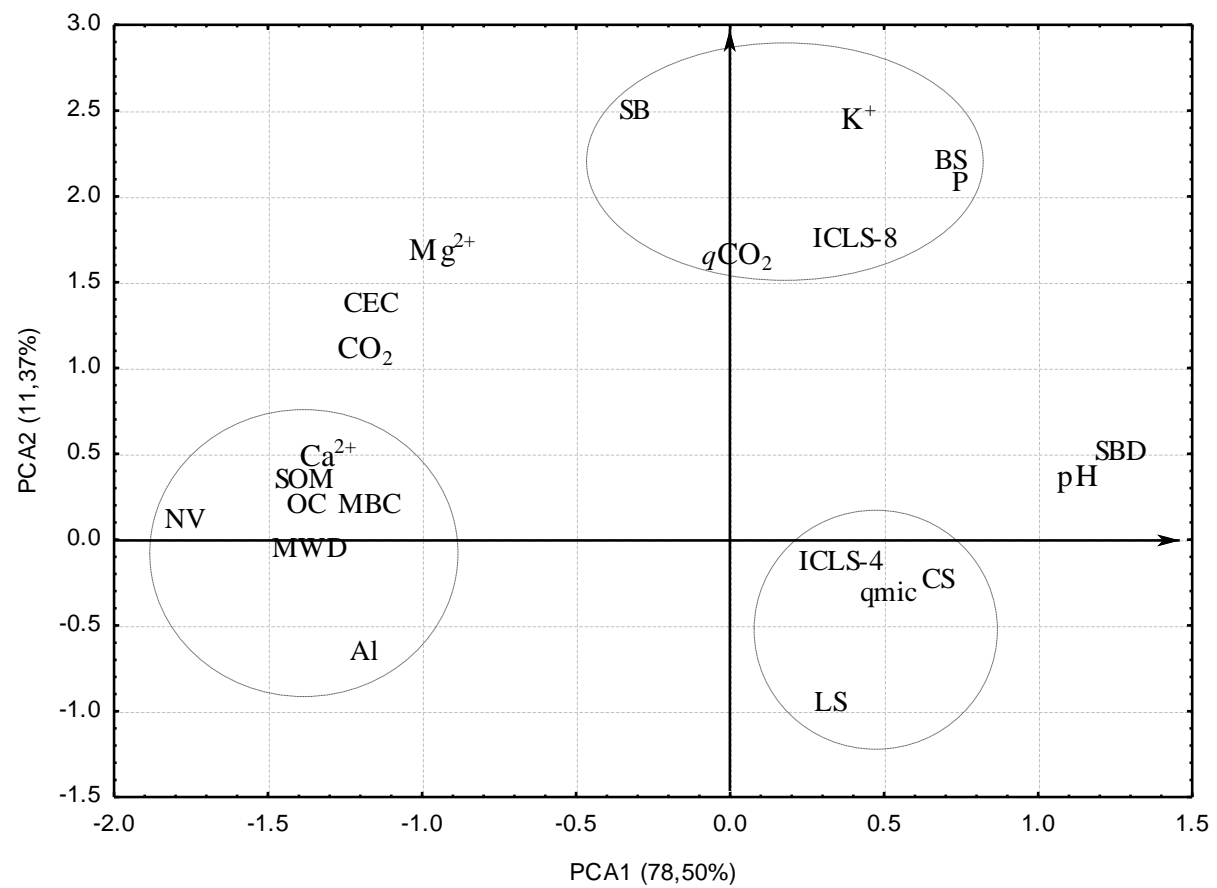

Fig 4. Biplot analysis showing relationship among the soil chemical, physical and microbial properties. NV Native "Cerrado" vegetation; CS_Crop system; LS_Livestock system; ICLS-4_integrated crop-livestock system with 4 years of implementation; ICLS8_integrated crop-livestock system with 8 years of implementation. Mean in each bar followed by the same letter are not significantly different at $\mathrm{p} \leq 0.05$ according to Scott Knott's test of mean. PCA1_ first principal components analysis; PCA2_second principal components analysis; CEC_Cation Exchange Capacity; $\mathrm{Ca}^{+2}$ Exchangeable $\mathrm{Ca}^{+2} ; \mathrm{Mg}^{+2}$ Exchangeable $\mathrm{Mg}^{+2}$; $\mathrm{SB} \_\mathrm{Sum}$ of Base; $\mathrm{K}^{+}$Exchangeable $\mathrm{K}^{+}$; Al_Exchangeable Aluminum; OC_Organic Carbon; SOM_Soil Organic Matter; MWD_Mean Weight Diameter; BS_Base Saturation (\%); P_Phosphorus Content; $q \mathrm{CO}_{2}$ metabolic quotient for $\mathrm{CO}_{2}$; $\mathrm{MB} \_$Microbial Breathing; MBC_Microbial Biomass Carbon; $q$ MIC_Quotient Microbial; SBD_Soil Bulk Density; pH_pH in $\mathrm{CaCl}_{2}$.

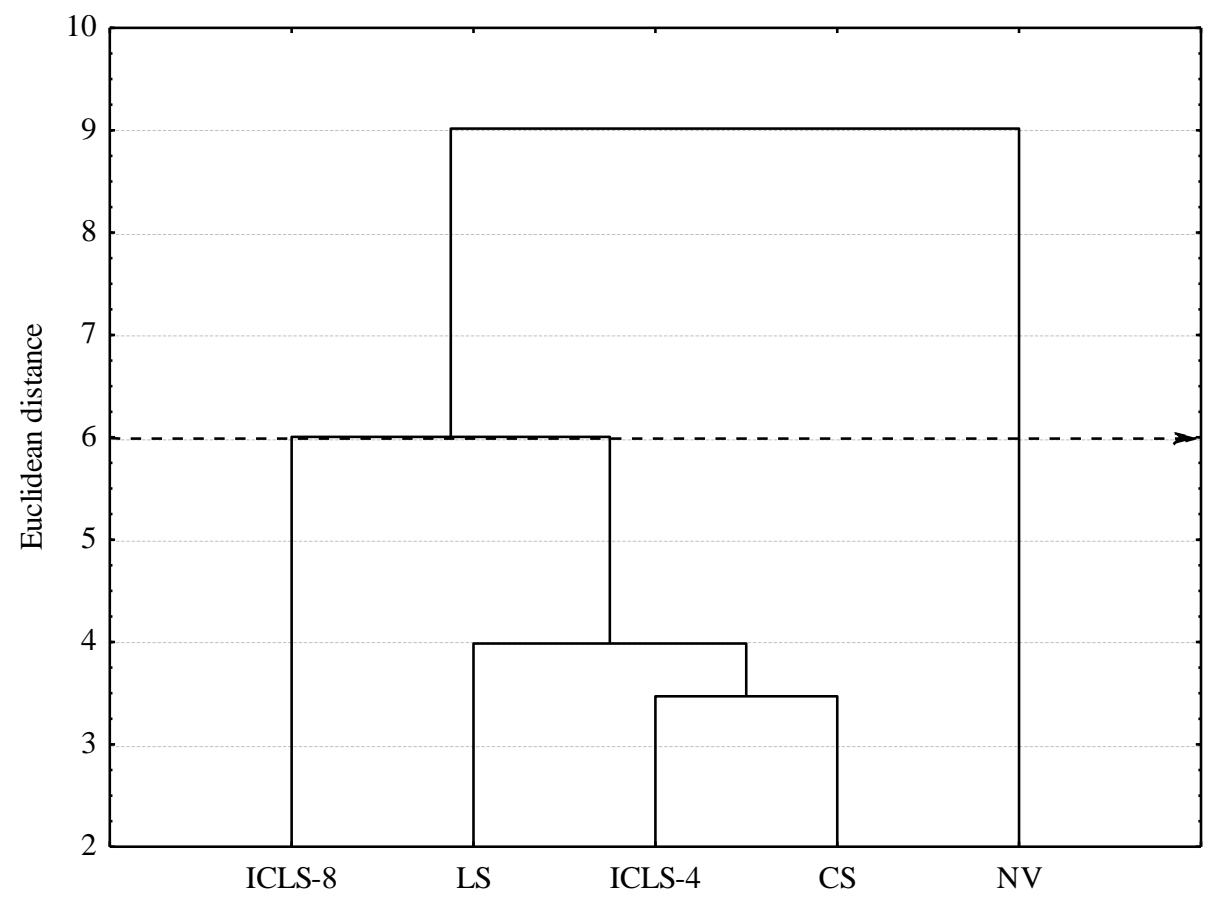

Fig 5. Dendrograms derived from the grouping analysis of agricultural management systems assessed. NV_Native "Cerrado" vegetation; CS_Crop system; LS_Livestock system; ICLS-4_integrated crop-livestock system with 4 years of implementation; ICLS8_integrated crop-livestock system with 8 years of implementation. 
these species overcome these constraints in uptake $\mathrm{P}$ in enough quantity for growth (Ramos et al., 2009). On one hand, no difference $(p>0.05)$ was observed among the agricultural systems, on the other, the SOC decreased significantly $(p \leq 0.01)$ in all agricultural system in comparison with the native "Cerrado" vegetation (Fig 1E). The SOC decreased $47.5 \%$ in relation to the native "Cerrado" vegetation and cation exchange capacity (CEC) decreased as well, these results are in accordance to Kara and Bay (2014). The SOC stocks in native vegetation is in balance because of the absence of tillage, however, when the native vegetation is replaced by crops or pastures, the soil tillage increases the mineralization process in SOM, which associated with the low input of above-ground dry matter from plants, results in low SOC stocks (Bayer and Mielniczuk, 2008; Kara and Baykara, 2014). The positive effect of above-ground dry matter on soil chemical was observed by Laudicina et al. (2011), the positive effects are associated with the no-till that improves the stability of soil aggregate, which is essential for the SOM protection against oxidation.

In relation to base saturation, no significant $(\mathrm{p}>0.05)$ difference was obtained among the treatments (Fig 1F). There was increase in soil fertility over time adoption of agricultural management system, particularly the exchangeable $\mathrm{K}^{+}$and $\mathrm{K}^{+}$ saturation (Fig 1B and G). This nutrient is quite important in Brazilian "Cerrado" due to the low content in soil and high cost of this income for farmers, nevertheless the increase of exchangeable $\mathrm{K}^{+}$may decrease the application of $\mathrm{K}^{+}$source in croplands under integrated crop-livestock systems, and these may lead to a sustainable agricultural system. The highest exchangeable $\mathrm{K}^{+}$in ICLS- 8 can be due to the highest capacity of Brachiaria spp in recycling $\mathrm{K}^{+}$, associate with fast release of $\mathrm{K}^{+}$from dry matter of Brachiaria spp, because $\mathrm{K}^{+}$is shown in plants in ionic form which contribute to a fast release to soil promoting availability of this nutrient. As reported by Garcia et al. (2008), Brachiaria brizantha showed high capacity in above-ground dry matter production and $\mathrm{K}^{+}$recycling, resulting in increasing exchangeable $\mathrm{K}^{+}$in topsoil.

The application of $\mathrm{K}^{+}$fertilizer sources in agricultural systems has been used without the consideration of the input that crop and animals residues can increment in soil, this way the application of $\mathrm{K}^{+}$fertilizer source can be taken in overdose. Over time adoption of ICLS, there was increase in $123 \%$ of exchangeable $\mathrm{K}^{+}$in ICLS- 8 in comparison with ICLS-4 (Fig 1G). These results can be associated with bovine urine and dung deposited, that are important to recycle $\mathrm{K}^{+}$in ICLS, as reported by Diogo et al. (2013), the quantity of recycling $\mathrm{K}^{+}$by cattle range from $3.0-5.6 \mathrm{~kg} / \mathrm{yr} / \mathrm{head}$, that can be available for plant uptake. The presence of cattle can modify the soil nutrient availability and aggregation, which can improve soil quality (Carvalho et al., 2010). As reported by Vendramini et al. (2007), the nutrient recycling can decrease the overdose of fertilizer in agricultural lands and avoid the contamination of environment. The exchangeable $\mathrm{Mg}^{+2}$ in the CS and LS showed smaller values, in comparison to NV, ICLS-4 and ICLS-8 (Fig 1H). In the case of exchangeable $\mathrm{Mg}^{+2}$, even in ICLS-8 that showed better conditions in chemical properties, this value is not in adequate amount, because the adequate values should be above $5.0 \mathrm{mmol}_{\mathrm{c}} \mathrm{dm}^{-3}$ (Fig $\left.1 \mathrm{H}\right)$. It demonstrates that the lime broadcast in this soil is not in adequate amount or the type of liming with low $\mathrm{MgO}$ may be influencing these results. As reported by Vendrame et al. (2010), in evaluation of "Cerrado" soil, it was observed that $85 \%$ of the "Cerrado" soil samples were below the critical value of $5.0 \mathrm{mmol}_{\mathrm{c}} \mathrm{dm}^{-3}$ for exchangeable $\mathrm{Mg}^{+2}$.
Soil bulk density and mean weight diameter affects by replacement of native "Cerrado" vegetation to croplands

In relation to soil physical properties, the agricultural management systems promoted increase in the soil bulk density (SBD) and decrease in soil aggregate stability measured through the mean weight diameter (MWD) (Fig 2A and B). The effect of animal grazing in ICLS-4 and ICLS-8 associated with no-till can contribute to increase SBD in relation to the native vegetation, as well as in the treatment of crop system (CS) (Fig 2A). However, in the livestock system (LS), the SBD was smallest in comparison with CS, ICLS-4 and ICLS-8, this decrease in SBD is due to the tillage with disk arrow to incorporate the lime right before the sampling, and this procedure resulted in the decrease of SBD. As reported by Villamil et al. (2015), in no-till system it was observed 5\% of increasing in SBD in comparison to tillage system. However, even with the change in SBD in relation to native vegetation, the results found were smaller than the critical level for root growth that is $1.75 \mathrm{~kg} \mathrm{dm}^{-3}$, according to Reinert et al. (2008). The Pearson's correlation between SOC $v s$ MWD showed positive and strong $(\mathrm{r}=0.906)$. The SOC is an important factor to promote soil aggregate stability (Kara and Baykara, 2014), which can contribute in native vegetation to obtain higher aggregate stability and smaller SBD (Fig 2A and B), once the native vegetation showed 90\% more SOC in comparison with the other treatments.

\section{Soil microbial properties affects by replacement of native vegetation to cropland}

The microbial biomass carbon (MBC) was more sensitive to differ the native "Cerrado" vegetation (NV) than the other variables, this way, in $\mathrm{NV}$ the mean value of $\mathrm{MBC}$ was $553.89 \pm 37.57 \mu \mathrm{g} \mathrm{C} \mathrm{g}$ of soil, which was $141.7,147.6,176.5$ and $212.8 \%$ higher than CS, ICLS-4, ICLS-8 and LS, respectively (Fig 3A). The soil microbiology is strongly influenced by quantity and quality of SOM added by crop and forest residues, but these features should not be evaluated alone (Kara and Baykara, 2014). No difference in MBC was observed between CS and ICLS-4, however the highest microbial biomass efficiency was observed in ICLS-4, which showed smaller $\mathrm{CO}_{2}$ loss through microbial breathing (Fig 3B). It is possible that, the forage grass could contribute to high exudation of organic compounds throughout its roots, which can be used by microorganism as source of energy and carbon, increasing its diversity and population, according to Tisdall and Oades (1982). Over adoption time of ICLS, there was significant $(p \leq 0.05)$ decrease in $\mathrm{MBC}$ (Fig 3A). The ICLS-8 showed the smallest value of MBC in comparison with ICLS-4, CS and NV, this decrease was detected by the $\mathrm{CO}_{2}$ loss throughout the microbial breathing in the oldest ICLS-8, which showed higher $q \mathrm{CO}_{2}$ microbial biomass (Fig $3 \mathrm{C})$. High values of metabolic quotient for $\mathrm{CO}_{2}\left(q \mathrm{CO}_{2}\right)$ imply in less efficiency of MBC (Odum, 1969; Anderson and Domcsh, 1985), that can be due to some stress condition or unbalanced promoting higher $\mathrm{CO}_{2}$ loss per microbial unit in ICLS-8, resulting in small MBC efficiency. The ICLS-4 showed higher MBC efficiency with less value of $q \mathrm{CO}_{2}$, in comparison to ICLS-8, that showed the smallest efficiency among the treatments. Considering the chemical and physical properties assessed and historic of experimental site, in the ICLS-8 the discrepant results were the increment over than $100 \%$ in exchangeable $\mathrm{K}^{+}$and $\mathrm{P}$ content. It is important to evaluate if these high values of these variable can contribute to unbalance the mineral elements in soil, which can influence in microbial biomass efficiency. As reported by Odum (1969), in condition of stress the microbial biomass 
tries to repair the condition of unbalance deflecting the energy necessary to growth and production to maintain their own biomass. Anderson and Domcsh (1985) observed that the soil $\mathrm{pH}$ influenced in microbial biomass efficiency, they reported that in low $\mathrm{pH}$ occurs increase of $q \mathrm{CO}_{2}$ with consequent decrease in microbial biomass efficiency. Even not evaluated in this research, the fungi / bacteria ratio can be studied in future research, because it can influence in less fungi breathing by biomass unit and less value of $q \mathrm{CO}_{2}$. For microbial quotient $(q \mathrm{MIC})$, it was not observed any difference among the treatments; however, it is important to observe that, the result for $q \mathrm{MIC}(0.94 \%)$ in ICLS-8 is much less than the adequate for a balance integration system. As observed by Jenkinson and Ladd (1981) the adequate value should be $q \mathrm{MIC}$ equal to $2.2 \%$, values below are indicative that higher quantity of carbon is being lost to atmosphere and it reduces the quantity sequestrate in soil.

As reported by Muniz et al. (2011), they obtained in Brazilian "Cerrado" the value of $2.8 \% q \mathrm{MIC}$ after three years of forage grass, they concluded that in forage grass due to the permanent cover soil and no-till with absence of crops allow more favorable environment to development of microbial biomass in forage grass in "Cerrado". Higher values of $q$ MIC are due to increase in $\mathrm{MBC}$ that ought to be improved by better soil environment for microbial activity (Marinari et al., 2007). According to Kara and Bayara (2014), higher values of $q \mathrm{MIC}$ are results of more organic substrate labile available in soil, which allows higher microbial biomass carbon per unit of biomass.

\section{Biplot analysis for soil properties}

Though the principal components analysis (PCA) (Fig. 4), it was verified that the first principal component analysis (PCA1) respond to $54.77 \%$ of total variable, while the second principal components analysis (PCA2) was compounded by $27.6 \%$ of total variance, the joint of both PCA1 and 2 result in $83.37 \%$ of total variance. The LS, ICLS-4 and CS showed similarity in relation to $q \mathrm{MIC}$. These results showed similarity among the treatments in maintaining the organic substrate more labile in soil, although the presence of beef cattle in ICLS-4. According to Kara and Baykara (2014), the entrance of cattle in ICLS can increase the labile carbon because of animal excretion. The ICLS-8 differed chemically (P content, exchangeable $\mathrm{K}^{+}, \mathrm{SB}$ and $q \mathrm{CO}_{2}$ ) from the other treatments, which demonstrated increase in soil fertility over time adoption of ICLS (Fig 4). However, the ICLS-8 showed less value of microbial biomass efficiency than the other treatments, it suggests that some stress or unbalance factor is influencing in this variable and must be studied in future research. On one hand, the native "Cerrado" vegetation highlight for higher SOC and its positive impact on mean weight diameter and $\mathrm{MBC}$, on the other, this native vegetation has high content of aluminum that can impact negatively on microbial activity.

The metabolic activity in the soil is strongly influenced by the presence of roots and organic matter in process of mineralization. High content of SOC tends to maintain the microbial population more stable over time, probably because of the occurrence of ecologic niches by diversity of carbon source (Tisdall and Oades, 1982).

The purpose of conservationist system is to achieve the biologics, soil organic matter properties and physical conditions of native vegetation, including the quantity and quality of vegetal residues available to microbial under forest system (García-Orenes at al., 2010).

\section{Grouping analysis of agricultural management systems}

In the study of grouping analysis, it was observed the establishment of grouping with higher similarity, because of smaller Euclidian distance, it was made for CS, LS and ICLS-4, and two groups, ICLS- 8 and NV that showed to be dissimilar from the other group and itself (Fig 5).

The first group formed (ICLS-8) was jointed isolate from the other and showed $70 \%$ of similarity with the $\mathrm{NV}$, while the CS showed $45 \%$ of similarity with $\mathrm{NV}$ and $55 \%$ of similarity for ICLS-4 and CS (Fig 5).

In analysis of physical, chemical and microbial soil data, it was observed that the ICLS-4 and CS are similar, even with the presence of beef cattle in ICLS-4. It was observed that over implementation time of ICLS, from 4 years to 8 years, the similarity with the $\mathrm{NV}$ increase, in term of physical, chemical and microbial properties (Fig 5). These results are quite important because the $\mathrm{NV}$ is a system in balance, with biologic and microbial activity adequate, besides the diversity in vegetation (Kara and Baykara, 2014). This study reassures that time is an important factor to achieve sustainable agricultural management system. The grazing animal can modified positively the dynamic of nutrients and soil aggregation, increasing soil quality. Even with low diversity in the system, the integration between forage grass and crops increase the biomimetism of nature and permits a better organization to achieve an upper system (Carvalho et al., 2010).

The Euclidian distance between ICLS-4 and CS was 35\%, it means that these systems showed respectively $65 \%$ and $60 \%$ of similarity with the LS. The similarity can be explain because the soil in LS remains 14 years in no-till system and the soil sample in this site was taken 40 days after the tillage with disk arrow, this way, these results show that even with the soil tillage the soil environment revealed high similarity with CS, because of the short time of tillage.

\section{Materials and Methods}

\section{Site description and soil}

This research was carried out on a farm with different types of agriculture management systems, and it was used a native "Cerrado" vegetation to compare the systems. The experiment was evaluated in June 2009, the experimental site is located in the municipality of Maracaju, State of Mato Grosso do Sul, Brazil (approximately 21 $36^{\prime} 52^{\prime}$ 'S. $55^{\circ} 10^{\prime} 06^{\prime} \mathrm{W}$, average altitude $384 \mathrm{~m}$ above sea level). According to Köppen (1948), the region is classified as tropical climate of type Am, with rainy summer and dry winter. The average rainfall is $1.500 \mathrm{~mm}$ and average temperature of $22^{\circ} \mathrm{C}$.

The soil of experimental site is in a Rhodic Hapludox soil, classified according to Brazilian taxonomy (Santos et al., 2013), which is compounds in clay fractions by oxide and hydroxide of iron and aluminum. To characterize the experimental plots, it was sample and analysis the mineral granulometric fractions of the soil (Table 2), following the methodology of Claessen (1997).

\section{Experimental design and treatments}

The experimental design was set up in completely randomized with five treatments (agricultural management system) and five repetitions. In each experimental area, it was selected plots with five hectares, which was considered the experimental unit. The treatments adopted were several agricultural management systems as follow; NV_Native 
"Cerrado" vegetation; CS Crop system; LS Livestock system; ICLS-4_Integrated crop-livestock system with four years of implementation; ICLS-8_Integrated crop-livestock system with eight years of implementation.

\section{Historic of experimental site}

Native "Cerrado" vegetation (NV) is a forest area typically of Brazilian "Cerrado", this area was used as reference to compare with agricultural systems. The crop system (CS) was an area cultivated in no-till system for 23 years with soybean in spring-summer and maize in fall-winter. In the livestock system (LS), it was covered by forage grass (Brachiaria decumbens) for 25 years. The ICLS-4 was cultivated for 15 years with crops in no-till system. After this time, it was introduced the livestock in the system and defined as ICLS-4. The integrated crop-livestock system with eight years of implementation (ICLS-8) was cropped during 19 years with crop rotation in no-till system. After this time, it was introduced the livestock in the system and defined as ICLS with eight years.

\section{Chemical and physical soil measurement}

It was collected soil sample to determine chemical, physical and microbial properties inside plot with 5 ha. The sample soil depth was $0-10 \mathrm{~cm}$. The sample was taken in five different spot in each plot that was considered the repetition of each treatment. It was used Dutch auger type to sample the soil and trenches. It was accomplished five soil samples per plot, but all of them were mixed to form just one sample to be analyzed. In each sample plot, it was opened five trenches per plot. The dimension of the trenches was $35 \mathrm{~cm} \times 35 \mathrm{~cm}$ x 50 $\mathrm{cm}$ (width, length and depth).

The following parameters were evaluated in the soil sample; total acidity $\mathrm{pH} 7.0(\mathrm{H}+\mathrm{Al})$, phosphorus content, potassium exchangeable, aluminum exchangeable, calcium exchangeable, magnesium exchangeable, cation exchange capacity (CEC), base saturation (BS\%), calcium $(\% \mathrm{Ca})$, magnesium $(\% \mathrm{Mg})$, potassium saturation $(\% \mathrm{~K})$, soil organic carbon (SOC), soil bulk density (undisturbed soil sample), aggregate stability (mean weight diameter), according to Claessen (1997).

The aggregate stability was determined using sieving in water, after preview wetting per capillarity on a filter paper wetting. To set apart the class of aggregate size, it was taken sieving with mesh of $2 \mathrm{~mm}, 1 \mathrm{~mm}, 0.5 \mathrm{~mm}, 0.25 \mathrm{~mm}$ and $0.10 \mathrm{~mm}$, which was shaken in apparatus of Yooder during 15 minutes. After 15 minutes, the material remained in each sieve was set apart with current water, stocked in adequate recipient and dried in stove until constant weight. The following equation was used to determine the mean weight diameter (MWD); MWD $=\sum_{i=1}^{a}(x i w)$, in what $\mathrm{MWD}=(\mathrm{mm})$, $\mathrm{xi}=$ mean class diameter $(\mathrm{mm})$ and wi=proportion of each class in relation to the total.

\section{Microbial soil measurement}

In relation to the microbial properties, after the soil sampling, the samples were stored in a box with ice and right after, the samples were put in cold storage until the time of laboratory analysis. The analysis of microbial biomass carbon (MBC) was determined through the methodology of fumigationextraction, which was adopted the factor of correction to efficiency of extraction (kec) equal to 0.33 , as suggested by Vance et al. (1987), the organic carbon was determined by method of Mebius, modified by Yeomans and Bremner (1989). The basal breathing $\left(\mathrm{C}-\mathrm{CO}_{2}\right)$ was obtained by respirometry method $\left(\mathrm{CO}_{2}\right.$ evolution). The microbial quotient ( $q \mathrm{MIC})$, which is expressed in percentage $(\%)$ was calculated by the following equation: $(\mathrm{MBC} / \mathrm{OrgC}) \times 100$ and the metabolic quotient for $\mathrm{CO}_{2}\left(q \mathrm{CO}_{2}\right)$ was obtained by division of basal breathing values per microbial carbon $\left(\mu \mathrm{CO}_{2} / \mu \mathrm{g}\right.$ $\left.\mathrm{MBC}^{-1}\right)$.

\section{Statistical analysis}

The variables evaluated in this experiment were submitted to the analysis of variance (ANOVA) by the $F$-test. The mean was compared by Scott Knott test $(\mathrm{p} \leq 0.05)$. After standard of databank, it was applied multivariate analysis, so that, each variable got null mean and unit variance. It was run the grouped analysis, considering as coefficient of similarity between pairs of Euclidean distance local that is a coefficient of dissimilarity, as recorded by Sneath and Sokal (1973). The strategy of grouping analysis adopted was the Ward's method, so that the distance between two groups is defined as the sum of square between the two groups taken under all variables.

It was run the principal compounds analysis (PCA), that was used to explain the structure of variance and co-variance contained in original variables, which resulted in a small joint of linear combinations orthogenesis. In the PCA, the variance contained in each principal component (PC) is expressed by eigenvalues of standard matrix. The higher eigenvalues is associated with the first principal component, the second higher eigenvalue are associated to the second principal component (PCA2), until the minor eigenvalue be associated with the last principal component, what placed the first ones as the most important. This way, the first principal components (PCA1) explain the most part of variance of original variables. The PCA was used with the objective to build at the end a graphic with two dimensions in what it is possible to verify group resultants, what along with the dendrograms (grouping analysis) make possible the systematic study of the samples.

\section{Conclusion}

The replacement of native "Cerrado" vegetation to integrate crop-livestock systems promote decrease in soil organic carbon, microbial biomass carbon, soil aggregate stability and increase of soil bulk density. The integrate crop-livestock systems improve the "Cerrado" soil fertility over time adoption. Over time of integrate crop-livestock system adoption, it was revealed increased in quantity of exchangeable $\mathrm{K}^{+}$and $\mathrm{P}$ content in "Cerrado" soil. The integrate crop-livestock system with eight years of adoption showed soil environment nearby the native "Cerrado" vegetation. Even the difficulty in obtaining the same physical and microbial condition of native vegetation, it is important to keep in mind that, the results of this research point out quite important observations, because just no-till system is not enough to obtain improvement of soil quality and the integrate crop-livestock system can return the soil properties of native vegetation, furthermore in relation to the improvement of soil chemical in comparison to native vegetation.

\section{Acknowledgement}

The authors are grateful to Universidade Federal da Grande Dourados (UFGD) for the collaboration of researchers and financial support to the accomplishment of this work. 


\section{References}

Anderson JPE, Domsch KH (1993) The metabolic quotient of $\mathrm{CO}_{2}\left(q \mathrm{CO}_{2}\right)$ as a specific activity parameters to assess the effects of environmental condition, such as $\mathrm{pH}$, on the microbial of forest soil. Soil Biol Biochem. 25: 393-395.

Balota EL, Auler PAM (2011) Soil microbial biomass under different management and tillage systems of permanent intercropped cover species in an orange orchard. Rev Bras Cienc Solo. 35: 1873-1883.

Barroso CB, Nahas E (2005) The status of soil phosphate fractions and the ability of fungi to dissolve hardly soluble phosphates. Appl Soil Ecol. 29(1): 73-83.

Batlle-Bayer L, Batjes NH, Bindraban PS (2010) Changes in organic carbon stocks upon land use conversion in the Brazilian Cerrado: a review. Agric Ecosyst Environ. 137: 47-58.

Bayer C, Mielniczuk J (2008) Dinâmica e função da matéria orgânica. In: Santos G de A, Silva LS, Canellas LP, Camargo FAO (Ed.). Fundamentos da matéria orgânica do solo: ecossistemas tropicais e subtropicais. 2.ed. Porto Alegre: Metrópole. p.7-18.

Braz SP, Urquiaga S, Alves BJR, Jantaliab CP, Guimarães APP, Santos CA, Santos SC, Pinheiro EFM, Boddey RM (2013) Soil carbon stocks under productive and degraded Brachiaria pastures in the Brazilian cerrado. Soil Sci Soc Am J. 77(3): 914-928.

Carvalho PCF, Anghinoni I, Moraes A, Souza ED, Sulc RM, Lang CR, Flores JPC, Lopes MLT, Silva JLS, Conte O, Wesp CL, Levien R, Fontaneli RS, Bayer C (2010) Managing grazing animals to achieve nutrient cycling and soil improvement in no-till integrated systems. Nutr Cycl Agroecosys. 88: 259-273.

Chávez LF, Escobar LF, Anghinoni I, Carvalho PCF, Meurer EJ (2011). Diversidade metabólica e atividade microbiana no solo em sistema de integração lavoura-pecuariasob intensidades de pastejo. Pesqui Agropecu Bras. 46: 12541261.

Claessen MEC (Org.) (1997). Manual de métodos de análise de solo. 2.ed. revisão atualizada. Rio de Janeiro: EmbrapaCNPS. p.212.

Diogo RVC, Schlecht E, Buerkert A, Rufino MC, Wijk MT (2013) Increasing nutrient use efficiency through improved feeding and manure management in urban and peri-urban livestock units of a West African city: A scenario analysis. Agr Syst. 114: 64-72.

Fede KL, Panaccione DG, Sextone AJ (2001) Characterization of dilution enrichment cultures obtained from size-fractionated soil bacteria by biology communitylevel physiological profiles and restriction analysis of $16 \mathrm{~S}$ rDNA genes. Soil Biol Biochem. 33: 1555-1562.

Garcia MRL, Sampaio AAM, Nahas E (2011) Impact of different grazing systems for bovine cattle on the soil microbiological and chemical characteristics. $\mathrm{R}$ Bras Zootec. 40(7): 1568-1575.

Garcia RA, Crusciol CAC, Calonego JC, Rosolem CA (2008) Potassium cycling in a corn-brachiaria cropping system. Europ J Agronomy. 28: 579-585.

García-Orenes F, Guerrero C, Roldan A, Mataix-Solera J, Cerda A, Campoy M, Zornoza R, Barcenas G, Caravaca F (2010) Soil microbial biomass and activity under different agricultural management systems in a semiarid Mediterranean agroecosystem. Soil Till Res. 109: 110-115. IBGE (2004) Mapa de biomas do Brasil. Escala 1:5.000.000. Rio de Janeiro: IBGE, 2004
Jenkinson DS, Ladd JN (1981) Microbial biomass in soil: measurement and turnover. In: Paul EA, Ladd JN (eds) Soil biochemistry. Marcel Deker. p425-471.

Kaiser HF (1958) The varimax criterion for analytic rotation in factor analysis. Psychometrika. 23: 187-200.

Kara O, Baykara M (2014) Changes in soil microbial biomass and aggregate stability under different land uses in the northeastern Turkey. Environ Monit Assess. 186: 38013808.

Laudicina VA, Badalucco L, Palazzolo E (2011) Effects of compost input and tillage intensity on soil microbial biomass and activity under Mediterranean conditions. Biol Fertil Soils. 47: 63-70.

Marinari S, Masciandaro G, Ceccanti B, Grego S (2007) Evolution of soil organic matter changes using pyrolysis and metabolic indices: A comparison between organic and mineral fertilization. Bioresource Technol. 98: 2495-2502.

Matús P, Kubova J, Bujdos M, Medved J (2006) Free aluminum extraction from various reference materials and acid soils with relation to plant availability. Talanta. 70 : 996-1005.

Muniz LC, Madari BE, Trovo JBF, Catanhandê ISL, Machado PLOA, Cobucci T, França AFS (2011) Soil biological attributes in pastures of different ages in a croplivestock integrated system. Pesqui Agropecu Bras. 46: 1262-1268

Odum EP (1969) The strategy of ecosystem development. Science.

164: 262-270.

Peigné J, Ball BC, Roger-Estrade J, David C (2007) Is conservation tillage suitable for organic farming? Soil Use Manage. 23: 129-144.

Ramos SJ, Faquin V, Rodrigues CR, Silva CA, Boldrin PF (2009) Biomass production and phosphorus use of forage grasses fertilized with two phosphorus sources Rev Bras Cienc Solo 33: 335-343.

Reinert DJ, Albuquerque JA, Reichert JM, Aita C, Andrada MMC (2008) Limites críticos de densidade do solo para o crescimento de raízes de plantas de cobertura em argissolo vermelho. Rev Bras Cienc Solo. 32(5): 1805-1816.

Rosolem CA, Merlin A (2014) Soil phosphorus availability and soybean response to phosphorus starter fertilizer. Rev Bras Cienc Solo 38(5): 1487-1495.

Sá JCM, Lal R (2009) Stratification ratio of soil organic matter pools as an indicator of carbon sequestration in a tillage chronosequence on a Brazilian Oxisol. Soil Till Res 103: 46-56.

Santos HG, Jacomine PKT, Anjos LHC, Oliveira VA, Lubreras JF, Coelho MR, Almeida JA, Cunha TJF, Oliveira JB. (ed.) 2013. Sistema Brasileiro de Classificação de Solos. 3. edição revisada e ampliada. Brasília: Embrapa, $353 \mathrm{p}$.

Silva AP, Babujia LC, Franchinia JC, Souza RA, Hungria M (2010) Microbial biomass under various soil- and cropmanagement systems in short and long-term experiments in Brazil. Field Crops Res. 119: 20-26.

Sneath PHA, Sokal RR (1973) Numeral taxonomy San Francisco: WH Freeman, 573 p.

Syers JK, Johnston AE, Curtin D (2008) Efficiency of soil and fertilizer phosphorus: reconciling changing concepts of soil phosphorus behaviour with agronomic information FAO fertilizer and plant nutrition bulletin18,108 (FAO: Rome).

Thomas RJ (1995) Role of legumes in providing $\mathrm{N}$ for sustainable tropical pasture systems. Plant Soil. 174: 103118. 
Tisdall JM, Oades JM (1982) Organic matter and waterstable aggregates in soil. J Soil Sci. 33:141-163.

Valboa G, Lagomarsino A, Brandi G, Agnelli AE, Simoncini S, Papini R, Vignozzi N, Pellegrini S (2015) Long-term variations in soil organic matter under different tillage intensities. Soil Tillage Res. 154: 126-135.

Vance ED, Brookes PC, Jenkinson DS (1987) An extraction method for measuring soil microbial biomass-C. Soil Biol Biochem. 19: 703-707.
Vendrame PRS, Brito OR, Guimarães MF, Martins ES, Becquer T (2010) Fertility and acidity status of latossolos (oxisols) under pasture in the Brazilian cerrado. An Braz Acad Sci. 82(4): 1085-1094.

Vendramini JMB, Silveira MLA, Dubeux JR, Sollenberger LE (2007) Environmental impacts and nutrient recycling on pastures grazed by cattle. Rev Bras Zoot. 36: 139-149.

Villamil MB, Little J, Nafziger ED (2015) Corn residue, tillage, and nitrogen rate effects on soil properties. Soil Till Res. 151: 61-66.

Yeomans JC, Bremner JM (1989) A rapid and precise method for routine determination of organic carbon in soil. Commun Soil Sci Plan. 19: 1467-1476. 